surgical:treatment of spina hifida. Injone case, in a child of fifteen months, death followed immediately npon puncture of tha sac with a Pravaz syringe. In two cases he employed the method of Morton-pnnctnre, followed hy injection of iodo-glycerin $1: 40$. In tha first patient, a girl of five months, which seemed cured, convulsions and hydrocephalns appeared at the end of two months. The other child remained cnred. In two cases the author partly excised tha tumor. to which tha cord and nerves adhered. Both were cured, hut ona later developed hydrocephalus, and the other remained completely paralyzed. In a hoy of seventeen years, who had an enormous tnmor in the dorsal region, Tédenat excised and found a considerahla hiatus at tha spinous apophysis, and tha dissection of the tumor was very difficult. The patient recorered.

Broca, of Paris, reported ten eases upon which he operated, seven recovered and three died from infection, two remotely and one immediately. He has not ohserved death from shock from the operation, and the chloroform has heen well borne. The operation is immediately dangerous on account of the danger of infectlon. In regard to the definite results, hydrocephalus is frequently ohserved after apparent cure. Of seven patients cured hy operation, one was subjected to another operation later, the nature of which was unknown; two hecame hlind, and three developed bydrocephalus. One remained well at the end of a year.

In one of the hydrocephnlic children, Brocs drained the lateral ventricles after trephining, hut the patient died in twenty-fonr hours. In another cose, he made $n$ puncture in the inmhar region at the seat of the cicatrix, nnd then compressed the cranium hy diachylon bandnges, without any result. After excision of the spina hifida, hydrocephalus is the rule, nad in the presence of this condition the surgeon is helpless.

\title{
ON THe Dragnosis of Roprobe of the Integtine.
}

BEnNDr states (Deutsche Zeitschrift fir Chirurgie, 39 B., 5 t. 6 Heft) that after a contusion of the ahdomen the following conditions may be taken as indicative of rupture of the intestine:

1. The ahsence of liver-dulness (MIoritz).

2. Frequent and uncontrollable vomiting.

3. The appearance of peritonitis, if legions of the kidney, hladder, liver, and spleen can he excluded.

4. Spontaneous pain in the abdomen is not of itself of much diagnostic rnlue.

Regarding the advisahility of operating in these cases, tha author says:

1. If there is unmistakahle evidence of rupture of the intestine, immediate laparotomy is indicated.

2. Exploratory laparotomy after contusion of the ahdomen is usually to he avoided; in uncertain cases, expectant treatment should he adopted (Moty).

3. If soon after the injury (twenty-fonr to thirty hours) there are sigus of sepsis, operation is contraindicated. A low temperature with marked constitutional symptoms is an especially nnfarorahla condition.

4. Rapidity and delicacy are essential in operating for ruptura of the in. testine, especislly if peritonitis is present. Therefora, a long ahdominal 
years, while cases are recorded as having good health tbirteen, fourteen, and even twenty-geven years after operation.

There are various theories concerning the cause for the improvement in these cases, hnt they are all speculative. The subacnte or chronic ascitic form of tuhercular peritonitis is the most favorahle variety for this treatment. The dry and fibrino-plastic cases have not done well after operation.

Upon the theory that the presence of air in the peritoneal cavity exercised a destructive effect on the anaērobic miero-organisms, Folet inflated the abdomen with air, after withd rawing the fluid, in $\mathbf{n}$ case of tuhercular peritonitis that refused laparotomy. The patient improved, and eigbt months afterward was in a very satisfnctory condition. Mrosetig v. MIoorhof employed this treatment in the case of a child four years of age, but the air was sterilized by being passed throngh a solution of carholic acid. Folet objects to this procedure, and believes that the air in its normal condition is more efficient.

\section{A Rare Cage of Diveroent luxatios of Both Bowes of the FOREABMr.}

Divergent luxation of both bones of the forearm is of so rare an occurrence, as Bardenheur remarks, that anthentic cases are of interest to the surgeon. Petzholdr (Arch. Jür klin. Chir., 1894, Band 48, Heft 1) describes a case wbich is of great interest, since it is of an entirely new variety of tbis rare laxation. Tbe case related congisted not only in a luxation of the ulna posteriorly and the radius anteriorly, bnt the radins was also slipped inward to the inner border of tbe trocblear, over tbe fossa supratrocblearis, near the coronoid process of tbe ulna. Tbe luxation occurred in a cbild nine years ald and poorly developed, after a fall npon tbe bnnd of abont three feet; there was Bcarcely any sweliing, and nll the bony points could be made out easily.

Tbe prognosis in tbese cases as regards pronation and snpination is improved, as tbis case recovered both. In reducing these lurations tbe first attention shonld be given to reducing tbe radial lusation, and tben the ulnn, as the reduction of the radius is more dificult after tbe ulna has heen replaced.

\section{On The Treatarent of Hydronephrosis and Pyonephrosis.}

Crasree, writing on this suhject, states (Centralblatt für Chirurgie, 1894, No. 47) that the cruse of bydronephrosis is still in douht, excepting those cases depending upon obstruction hy n calcnlus. Tbe author suggests the possibility of an inherited tendency to hydronephrotic moving kidney. Normally, the lidney scarcely has n pelvis, but the calices discbarge their contents at the deepest portion into the nreter. If the ureter is fixed hy any adhesion, and the kidney falls downward and forward toward the middle line, the month of the ureter does not represent the deepest partion of the pelves, but a little above. In this way the collection of nrine in the kidney begins, and the accumulation and discharge alternate according to the position of the kidney. If the malposition continues, a kind of ralve-mechanism is formed at the mouth of the weter.

In regard to therapy, the remedy is to restore the moutb of the ureter to 
the lowest part of tbe pelvis. Nepbrectomy bas been recommended, but it seems unjustifiable to sacrifice such an important organ, and nepbrotomy is tberefore more suitahle.

Two cases are reported in wbicb tbe kidney was reacbed posteriorly tbrougb Bardenbeuer's flap incision, the nreter divided and transplanted in a slit made in the lowest portion of the bydronephrosis sac, which was opened and packed. It is not possible to prove tbat the function of tbe kidney bas been restored in eacb case.

\section{The Contagroussegs of Caxcer.}

At the eigbth session of the Congres Frangais de Cbirurgie, during the discussion of tbe "Etiology and Patbogenesis of Cancer," Goblior, of Reims, stated that tbe belief in a cancerous diatbeais has prevented a more general acceptance of tbe infectious natnre of capcer, wbicb, beginning as a local disease, affects the economy secondarily. The experiences of Hanall and MIoreau prove that cancer is in oculahle in nnimals of the same species. Experimenta] hetero-inoculation being established, tbe spontaneous hetero-inoculation. is possible, and remains for tbe clinic to prove. The rationgl proofs of the exterior origin of cancer and of the trangmission of cancer are drawn from the usual seat of neoplasms, from the intluence of lesions, irritation, or ulceration, and the numerous cases of accidental inoculation. The strongest evidence of this is furnished hy observations in the ruml districts. The unequal distrihution of capcer is well known, and can be explained only hy topographic, hydrograpbic, or other exterior causes in all the cases. On tbe other hand, there are verituhle cancor-centres, ahodes of cancer. Guelliot bas collected fifteen examples, emhmeing fifty victims; the inferepce of contagiousness naturally follows. More instructive are the cases of epitbeliomata occurring successlvely in persons accustomed to hnbitual cohabitation. Tbe autbor bas reported forty-two personal cases of this kind, wbicb, added to tbose already pullisbed, give one bundred nnd thirteen observations; in more than forty-five of these husband and wife were affected. Tbe interval wbich separates the appearance of the dimease in the two persons has not exceeded two years in more tban balf of the cases. All these ohservations force upon one the idea of direct or indirect transmission of cancer, which spreads as an infectious disease. The incuhation is from several months to two years, first localization, tben generalization. Tbe nppreciation of tbis fact implies in the future the application of efficacious propbylactic measures.

During the same discussion, Mlayet, of Lyons, expressed a helief in the cellular specificity. Luboratory experiments bave led bim to consider cancer is inoenlable, not only hy grafuing, but also by the juice. Tbe wbite rat is the most favorahle animal for carrying out these studies. He bas several times inocnlated wbite rats witb tbe juice of erncer obtained by the method of Brown-Sequard in extracting testicular extract, witb positive results in one case in tbree; at the autopsy cancerons deposits were found in tbe kidneys.

\section{The Treatment of Spina Bifida}

In a discussion on tbis snbject, at tbe recent session of tbe Congris Frangais de Cbirurgie, M. Ténen aT, of Montpellier, related his experience in the rot. 109, No. 6. -JUNE, 1895. 
incision, rapid, systematic examination of the intestine, avoiding rough tearing or handling; if possihle to avoid it, do not resect the intestine; employ simple Lemhert sntures, or at most a wedge-shaped resection of the injured portion of intestine, and close with a simple running suture including the muscular and serous costs. Flushing the abdominal cavity with antiseptic liquids is to he avoided.

\section{Indications for the Sunoical Treatarent of Cholelithiasig.}

Gensury gives the following indications for operation in cholelithiagis (Wiener medicinische Presse, 1894, No. 47):

1. Mromenlary danger hy hursting of the gnll-hladder, ohstruction of the intestine, heginning sepsis. If traces of sepsis are found, the necessity for operation hecomes imperative. Such crses may he cured hy expectant treatment, hnt the dnnger to life is greater than that incurred hy the operation.

2. Freguent ntlacks of colic and persistent icterus. Marked frequency of the attacks makes one apprehensive of danger to the patient. Further, the fhet of permnnent irritation is not to be underrated, hecause it may cause carcinoma. Pensistent icterus resnlts, as a rule, in the decline of the general health, so that one is ohliged to operate to improve the nutrition of the patient.

3. Inability to vork nnd constnnt pain. Even if there were no momentary danger to demand an operation, if the suffering of the patient prevents him from doing anything, surgical interference is indicated, especially if the patient is dependent upon his own exertions.

\section{Stertlization of the Hands wita Makble-dugt.}

WITrkowskr recommends (Therapeutische Afonatshefte, Bd. viii. p. 343) for sterilization of the hands, 1 purt of common soap, 3 parts of sieved marhledust, 4 per cent. lysol, and a little wax paste. Bacteriological experiments, after using this preparntion, show that it mny sefely replece all other disinfecting miethods, and renders the use of nlcohol unnecessnry.

\section{Appendix Calculi.}

Rochaz (Revue Stedicale de la Surise Romande, 1894, No. 12) concludes a valuahle article on the above suhject as follows:

1. Appendicitis is caused, in the great majority of cases, hy stercoral calculi, even though they he not found nt the operation. 2. Foreign hodies, proper, are very rare in appendicitis. 3. Worms are not-found in the appendix during life. 4. In the normal appendix the fecal matter is found most frequently in a fluid state. 5 . The calculi form in the appendix itself. 6 . Usually they are not multiple. $\pi$. Their general form is elongated, their color is generally hrownish, their consistence is as freqnently hnrd as soft. 8. On section, they commonly present a disposition to concentric layers. 9. The nnclens is, as a rule, of lighter color thnn the envelope; it is very rarely a foreign hody. 10. The chemical composition of appendix calculi closely corresponds to that of human feces. 11. Men are more suhject to appendicitis hy foreign hodies than women, and the majority of cases are ohserved hetween 